\title{
KOMPARATIVNAANALIZA UDŽBENIKA ZA ENGLESKI I ŠPANSKI JEZIK NA NIŽIM GODINAMA OSNOVNIH AKADEMSKIH STUDIJA NA UNIVERZITETU SINGIDUNUM
}

\author{
Valentina Bošković Marković, \\ Maja Veljković Michos
}

Univerzitet Singidunum, Beograd, Srbija
Odgovorno lice:

Valentina Bošković Marković

e-pošta:

vboskovic@singidunum.ac.rs

\section{Rezime:}

Jezik za posebne namene ili jezik struke je termin koji je postao popularan šezdesetih godina. Za razliku od opšteg jezika, učenje jezika struke se definiše kao sticanje onih znanja koje određeni stručnjak ima iz date oblasti na maternjem jeziku, a kojima treba da ovlada i na drugom stranom jeziku. Imajući u vidu da je jezik struke u savremenom društvu neophodan u svim oblastima poslovanja- marketingu, turizmu, hotelijerstvu, bankarstvu, itd- ovaj rad je posvećen analizi udžbenika za engleski i španski jezik na Poslovnom fakultetu i Fakultetu za turistički i hotelijerski menadžment na Univerzitetu Singidunum, kako bismo uvideli da li postoje udžbenici koji su namenjeni za usavršavanje jezika za posebne namene na I i II godini osnovnih akademskih studija. Pored teorijskog dela, rad predstavlja i analizu potreba koja je urađena sa studentima i studentkinjama nižih godina studija na predmetima Engleski i Španski jezik kako bismo zaključili da li je uvođenje jezika struke neophodno već od samog početka školovanja, ili samo na višim godinama studija.

Ključne reči:

španski, engleski, jezik struke, analiza potreba.

\section{UVOD}

Prilikom kreiranja plana i programa nastave španskog i engleskog kao stranih jezika na univerzitetskim studijama, kontekst struke je neophodno uzeti u obzir kao prioritetni element. U prilog tome govore i sve brojnija izdanja izdavačkih kuća koje poslednjih godina sve više pažnje poklanjaju izučavanju jezika za posebne namene, a naročito kada se radi o sektorima koje se bave pružanjem usluga (poslovni, pravni, medicinski, turistički, prevodilački). Dok je engleski jezik najčešće obavezan predmet na osnovnim studijama, te nema potrebe za analizom potreba studenata, poznavanje motiva studenata za odabir španskog jezika kao drugog stranog jezika omogućuje nam da ih lakše uključimo u nastavni proces i da studenti sa nastavnikom aktivno učestvuju u kreiranju nastavnog materijala, kao i samog toka nastave. Budući da se analizom potreba studenata dizajnira određeni kurs, trebalo bi da im on pruži potrebne alate za buduću upotrebu jezika, kako u ličnom, neposrednom okruženju, tako i u struci, u poslovnom okruženju. Podučavanje jezika struke ne podrazumeva samo uvođenje stručne leksike, već i njegove manifestacije u govoru i pisanju, vodeći računa o potrebama učesnika u 
komunikativnim razmenama. Prema tome, studentima je neophodno obezbediti potrebne lingvističke, diskurzivne i gramatičke alate koji su u upotrebi u određenim komunikativnim situacijama i kontekstima koje smatramo stručnim. Stoga je ovaj rad posvećen komparativnoj analizi udžbenika koji se koriste na nižim godinama osnovnih akademskih studija na predmetima Engleski jezik 1 i 2 i Španski jezik 1 i 2 na Poslovnom fakultetu i Fakultetu za turizam i hotelijerski menadžment Univerziteta Singidunum.

\section{JEZIK I STRUKA}

\section{Jezik internacionalne komunikacije}

Španski jezik je definitivno "u modi" u celom svetu, prema poslednjim podacima godišnjeg izveštaja Instituta Servantes, ovaj drugi svetski jezik po broju govornika (572 miliona) uči više od 21 miliona studenata kao strani jezik. Obavezno se izučava na svim nivoima obrazovanja u SAD, dok je u Velikoj Britaniji preporučen kao strani jezik budućnosti. Drugi jezik je po korišćenju na društvenim mrežama, a Španija je treća zemlja u svetu po izvozu knjiga [1]. Što se turizma tiče, Španija je u 2017. godini postigla maksimum po broju turističkih poseta i prihodima od stranih turista, postavši po prvi put druga svetska turistička destinacija, što doprinosi povezivanju jezika sa turizmom. [2]

Studenti Fakulteta za turistički i hotelijerski menadžment Univerziteta Singidunum oduvek su se većinom opredeljivali za španski kao drugi strani jezik, u odnosu na ostale jezike. Razlozi su različiti, ali studenti najčešće kao razlog navode činjenicu da je španski jezik lep i lak za učenje, a pored toga važan za sporazumevanje i poslovnu komunikaciju. Opredeljuju se da studiraju turizam zato što vole da putuju i upoznaju svet, kao i zbog zapošljavanja u turističkom i hotelijerskom sektoru. Iz istih razloga na ovom fakultetu biraju španski kao drugi strani jezik.

\section{Jezik struke u oblasti turizma i poslovanja}

Ipak, u didaktičkom kontekstu, treba imati u vidu definiciju i opis odrednice "jezika turizma" koja ima složeniju fizionomiju. U jednoj od malobrojnih studija o jeziku turizma [3] definiše se kao skup "mikro jezika" međusobno povezanih (mikro jezik hotelijerstva, saobraćaja, međunarodnih poslova, istorije umetnosti, gastronomije, itd) koji mogu u manjem ili većem obimu biti zastupljeni u stručnim sektorima (hoteli, restorani, turističke agencije, itd). Međutim, leksičke potrebe učenika prevazilaze usvajanje terminologije jednog sektora. Postoji uska i šira stručna terminologija [4]. Stručni jezik u užem smislu koji se odnosi na turističku strukturu (ugostiteljstvo, agencije, transportna preduzeća, itd) takođe se imenuje i kao tzv. specijalizovani jezik ili žargon koji se koristi među učesnicima u komunikaciji u okviru jednog sektora. Pored toga, jezik turizma podrazumeva i druge tematske elemente koji su u vezi sa tipologijom turističkih destinacija, kao i povezane kulturološke aspekte (geografija, istorija, umetnost, tradicije) osobene za svaku jezičko-geografsku oblast.

Značaj turizma u svetskoj ekonomiji takođe je uticao na leksički fond koji ga karakteriše. Zbog toga je važno da, pored učenja i usvajanja vokabulara i razvijanja jezičkih kompetencija, nastava stranog jezika za posebne namene bude povezana i sa društvenim ponašanjem, odnosno da se ozbiljnija pažnja posveti veštinama međukulturalne komunikacije. $\mathrm{U}$ tom smislu, istakli bismo tri osnovna aspekta nastave jezika struke:

1. usvajanje vokabulara struke, ili stručne terminologije, koji se sastoji pre svega od stranih reči anglosaksonskog porekla (uz izuzetke, kao što je, na primer reč hotel, francuskog porekla). Tako, na primer, reč koja difiniše čitav sektor, turizam (turismo), preneta je iz engleskog (tourism) i prihvaćena u svim evropskim jezicima, uz fomalne adaptacije (iako reč izvorno potiče od francuske odrednice "Grand Tour"). U španskoj turističkoj terminologiji, najveći procenat anglicizama zabeležen je u sektoru koji se odnosi na putovanja i saobraćaj [5].

Međutim, u hotelijerstvu, i pored brojnih anglicizama u španskom leksičkom fondu postoji veliki broj odrednica domaćeg porekla, i razvijena je takovana "tradicionalna terminologija" u vezi sa tipovima smeštaja (alojamiento) i različitih smeštajnih objekata ( "posada", "hospedería", "casona", "cortijo", "pazo", "bodega", "molino", itd).

U gastronomiji je naročito prisutna bogata domaća leksika kada se govori o regionalnim kuhinja i nacionalnim jelima Španije („paella valenciana“, „gazpacho anadaluz", „tortilla española“, „cocido madrileño“, itd.)

2. Paralelno sa učenjem vokabulara, gramatika je preduslov za razvijanje jezičkih i komunikativnih veština studenata. Gramatičke strukture koje predstavljaju najviše poteškoća studentima moguće je uvežbavati i usvajati kroz konkretne primere njihove upotrebe u različitim komunikativnim situacijama stručnog konteksta. Važno je da studenti razumeju zbog čega je korisno naučiti određenu strukturu, 
odnosno, koliko je primenljiva u upotrebi u različitim kontekstima, i koliko olakšava sporazumevanje u komunikativnim razmenama sa izvornim govornicima.

3. Razvijanje veština interkulturalne komunikacije je veoma značajan aspekt u nastavi jezika, kao i u sektoru biznisa i turizma. Interkulturalni pristup koji preovladava u nastavi stranih jezika promoviše podizanje svesti studenata u vezi sa kulturološkim osobenostima koje se odražavaju kroz jezik. U poslovnom svetu razvijanje interkulturalnih kompetencija predstavlja osnovni preduslov kako bi se izbegli nesporazumi u poslovnoj komunikaciji. [6]

Kao osnovni preduslov za budućeg profesionalca u oblasti turizma, interkulturalne kompetencije podrazumevaju sledeće veštine i sposobnosti:

a) Prepoznavanje i prevazilaženje stereotipa u vezi sa drugom kulturom.

b) Razvijanje komunikativnih i pragmatičnih veština: poznavanje društvenog ponašanja i sposobnost interakcije u različitim komunikativnim situacijama diatopičkim varijetetima španskog, odnosno "prostornim, geografskim varijetetima”.[7]

c) učenje i poznavanje drugih disciplina (geografija, umetnost, istorija, folklor, gastronomija, itd.) kao i njihovo povezivanje sa jezičkim veštinama.

Kada je reč o jeziku poslovanja, upravo iz ovih potreba smo i došli do termina ,jezik za posebne namene“ ili „jezik struke“ još šezdesetih godina, kada je došlo do ekspanzije engleskog jezika u oblasti poslovanja na svetskom nivou. Industrijska revolucija, razvoj konzumerskog društva i razmena dobara uticali su na sve veću potrebu za opštim engleskim jezikom, ali i za jezikom koji bi tačno definisao određene termine na globalnom nivou, odnosno za jezikom struke. Stoga se nakon šezdesetih godina pojavljuju upravo kursevi engleskog jezika za posebne namene, kako bi što veći broj njegovih govornika bio osposobljen za poslovanje na svetskom nivou. Danas, poslovni engleski jezik je sastavni deo svakog ozbiljnog silabusa na univerzitetskom nivou i neizostavni deo vokabulara svakog ozbiljnog govornika engleskog jezika.

\section{Opšti kurs jezika ili kurs za posebne namene?}

Postavlja se pitanje kada uvesti kurs jezika za posebne namene: da li treba podučavati prvo opšti jezik od početnog nivoa (A1), a stručni uvesti na višim nivoima, ili je efikasnije uvesti jezik struke od prvog časa učenja stranog jezika?
Oba rešenja su ispravna i imaju odgovarajuće teorijske osnove. Izbor će zavisiti ne samo od toga da li je i koliko vrednovana autonomija jezika za posebne namene u odnosu na opšti jezik, već od profila učenika, odnosno grupe učenika/ studenata.

Većina obrazovnih ustanova se danas opredeljuje za razvoj jezičkih kompetencija učenika na opštem jeziku, da bi se učenici pripremali za jezik struke na višim nivoima znanja. To je naročito slučaj sa drugim stranim jezikom, koji je u našim obrazovnim institucijama nije statusno određen kao jezik struke. Međutim, čak i engleski jezik, koji je danas globalni lingua franca, nije u školama i na fakultetima karakterisan i planiran kao jezik struke, već kao opšti jezik.

S druge strane, u poslovnim organizacijama učenje jezika struke je produktivnije kada se polaznici kursa od početka izlažu komunikaciji i raznorodnim tekstovima stručnog jezika: reč je o poznavaocima stručne terminologije na maternjem jeziku koji usvajaju strani jezik svoje struke. Ipak, ova prednost "učenika - stručnjaka" izazov je za profesora, koji ne mora nužno da poseduje teorijska znanja struke, budući da je njegova "misija" podučavanje jezika - uz najsavremeniju metodologiju, nastavna sredstva i moderne tehnologije- u cilju usavršavanja jezika i razvijanja veština komunikacije kod studenata na stranom jeziku.

U svakom slučaju, profesori jezika struke bi trebalo da budu u stanju da:

- prepoznaju karakteristike jezika struke na svim nivoima učenja;

- analiziraju potrebe učenja konkretne grupe učenika;

- kreiraju silabus i korpus tekstova koji odgovaraju potrebama kursa;

- daju uputstva u vezi sa pravilnom upotrebom rečnika (jednojezičkih i višejezičkih, opštih i stručnih);

- kreiraju dvojezične, tematske glosare;

- daju uputstva u vezi sa korišćenjem elektronskih izvora i sadržaja sa interneta.

Kada je reč o pristupu, učenje jezika kroz zadatke (Enseñanza por tareas/ Task based learning) izgleda kao najadekvatniji kada se radi o španskom kao drugom stranom jeziku u univerzitetskoj nastavi smera turizam u hotelijerstvo i jedan od najadekvatnijih kada se radi o engleskom kao prvom stranom jeziku. Takođe, pristup učenju kroz zadatke je usko povezan sa nastavom jezika struke. U ovom slučaju, student je aktivan učesnik u nastavi, ne prisustvuje času pasivno zapisujući i 
ponavljajući reči i stručne izraze koje mu je profesor na času prikazao. Naprotiv, profesor predlaže komunikativne zadatke i organizuje studente u manje grupe na način da se simuliraju realne situacije (organizacija putovanja; rezervacije smeštaja, prevoza, poslovni sastanak, pisanje poslovnih mejlova, itd.), čime se podstiče saradnja i timski rad i simulira ambijent sa kojima će se susretati u budućem poslovnom okruženju.

\section{OSMIŠLJAVANJE PLANA I PROGRAMA}

\section{1) Analiza potreba}

Na prvom mestu, potrebno je uraditi analizu konkretnih potreba grupe studenata kako bi se zaključilo da li je za njih pogodniji opšti kurs jezika ili kurs jezika za posebne namene (jezik struke) kako bi se ispunili nastavni ciljevi.

Pre planiranja programa, potrebno je uraditi lingvističku analizu. Takođe je važno da se na prvim časovima uradi anonimna anketa ili upitnik, na osnovu kojeg bi se stekla slika o potrebama grupe studenata na konkretnom kursu. Na osnovu upitnika koji je rađen sa studentima svih nivoa učenja (A1, A2, B1), veoma je visoko vrednovana nastava španskog i engleskog jezika koji studenti pohađaju, i sugestije ili primedbe ne odnose se tok nastave, niti su studenti ukazivali na potrebu za bilo kakvim promenama u pristupu, metodima i nastavnim sadržajima.

Kada je reč o kursevima engleskog jezika na Univerzitetu Singidunum, bitno je napomenuti da se na nižim godinama studija Poslovnog fakulteta radi opšti engleski (udžbenik: Complete First Certificate in English, Cambridge University Press), dok se na višim godinama studija radi jezik struke (Business Benchmark, Cambridge University Press), pri čemu do završetka studija studenti dostižu C1 nivo prema Zajedničkom evropskom okviru za jezike. Prema nastavnom planu i programu, ovakav vid nastave pokazao se kao uspešan u dosadašnjoj nastavi, jer se tokom nižih godina studenti podsećaju gradiva koje je pređeno u srednjoj školi, a odnosi se na gramatičke i opšte vokabularne jedinice, dok oni studenti koji nemaju prethodno stečeno znanje takođe dobijaju adekvatno znanje koje je odlična osnova za kasniju jezišku nadogradnju. Tokom viših godina studija, nivo znanja svih studenata postaje približno ujednačen i svi su podjednako osposobljeni za usvajanje novih vokabularnih jedinica koje su u vezi sa jezikom struke (biznis, marketing, HR, itd).
Kada je reč o učenju jezika struke za drugi strani jezik, on nije statusno određen u našoj obrazovnoj ustanovi. Drugi strani jezik izučava se, prema akreditovanom silabusu, kao opšti jezik sve četiri godine na Fakultetu za turistički i hotelijerski menadžment, od početnog do srednjeg nivoa znanja (A1-B1- prema Zajedničkom evropskom okviru za jezike).

\section{2) Kreiranje programa po nivoima i izbor didaktičkog materijala}

Prema predlogu ALTE (Association of Language Testers in Europe) i dokumentu D2 koji se odnosi, između ostalog, na to šta osoba "može da uradi" na jeziku iz kojeg se testira ("Can Do statements") za oblast turizma (Resumen de especificaciones de Sociedad y Turismo de $A L T E$ ), navodi se organizacija specifikacija sposobnosti jezičkog usvajanja ("može da uradi”), a u vezi su sa ALTE i sa Jezičkim referentnim okvirom. Kada je u pitanju skala veština "može da uradi" sastoji se od oko 400 specifikacija podeljenih u tri oblasti: Društvo i Turizam, Posao i Studije. Ovo su tri oblasti koje najviše interesuju većinu učenika stranog jezika. Svaka oblast podeljena je na više podoblasti, tako da oblast "Društo i Turizam" sadrži sledeća poglavlja: Kupovina (Ir de tiendas), Ishrana u restoranima (Comidas en restaurantes), Smeštaj (Alojamiento), itd. Ove smernice su neophodne pri osmišljavanju i planiranju nastavnog sadržaja i planiranja kursa. Sadržaji koji su u vezi sa oblasti "turizam" razlikuju se po temama, aktivnostima, kontekstu i jezičkim veštinama.

Kada se nastavnik opredeljuje za nastavni materijal, udžbenik na prvom mestu (libro del alumno) potrebno je da proceni da li odgovara potrebama grupi studenata (uzrast, interesovanja, prethodno znanje, itd). Budući da se radi o studentima turizma, nastavni materijal treba da ima i specifične sadržaje iz oblasti turizma. Naši studenti poseduju određena teorijska i praktična znanja u vezi sa poslovanjem u svim sektorima turističke privrede koja su stekli iz stručnih predmeta. Pored maternjeg jezika, svoja znanja i veštine razvijaju i na engleskom jeziku. Nastava drugog stranog jezika je, zbog toga, usmerena na razvijanje osnovnih komunikativnih veština i na jezičke veštine potrebne za interakcije u ličnom, akademskom i stručnom kontekstu.

Budući da nijedan udžbenik nije idealan za te namene, niti je jedini izvor znanja i informacija, potrebno je selektivno se odnositi prema sadržajima i odabrati teme, tekstove i zadatke iz različitih izvora kako bi se postigla optimalna adaptibilnost sa nivoima znanja studenata u cilju realizacije didaktičkih ciljeva. 
Pored štampanih izdanja, internet obiluje sadržajima koji se mogu upotrebiti u nastavi jezika. Upravo zbog toga važno je uputiti studente na odgovarajuće i proverene digitalne sadržaje kako ne bi pristupali onima koji nisu relevantni, aktuelni ili upotrebljivi za njihovo usavršavanje znanja.

U tom smislu, navešćemo neke internet stranice i portale turističkih institucija, kao i druge korisne izvore gde se nalaze aktuelne i značajne informacije o turizmu, kulturi i ekonomiji Španije, kao i drugim temama koje su aktuelne i interesantne za studente turizma i hotelijerstva:

- turističke institucije (www.red2000.com, www. spain.info, www.turespaña.com, itd.)

- španska kuhinja (www.afuegolento.com, www. spain.info/es/consultas/gastronomía, www.spanish-food.org

- saobraćaj (www.iberia.com, www.renfe.es, www. aena.es ,)

- hoteli (www.es.hoteles.com, www.rumbo.es, www. iberostar.com )

- elektronski mediji (informativne publikacije) (www.elpais.es, www.elmundo.es, www.abc.es, www.elperiodico.es, www.estrelladigital.es, itd.);

- televizijski kanali na internetu (www.rtve.es, www. telecinco.es, www.antena3tv.es, www.cplus.es, itd).

Takođe, u nastavku se navode odabrane knjige koje su do sada objavljene, a koje se koriste kao komplementarni materijal na kursevima španskog jezika:

1. Aguirre Beltrán, Blanca (1994): El español por profesiones, Servicios Turísticos, SGEL, Madrid.

2. González Marisa, Felipe Martín, Conchi Rodrigo, Elena Verdía, (1999): Socios 1 y 2: curso básico de español orientativo al mundo del trabajo, Difusión, Barcelona.

3. Moreno, Concha y Martina Tuts (1997): El español en el hotel, SGEL, Madrid.

4. Varela Raquel, Hermoso Ana, Goded Margarita (2005): Bienvenidos, Nivel 1 (A2), Español para Profesionales, Turismo y Hostelería, enCLAVEele, Madrid

5. Hermoso Ana, Centellas Aurora, Palacios Elena, Goded, Margarita y Varela Raquel (2016): Bienvenidos de nuevo A1-A2, enCLAVEele, Madrid

6. Marisa de Prada, Pilar Marcé (2013): Entorno laboral (Nivel A1/B1), Edelsa, Madrid
7. Cristina M. Alegre Palazón, Leonor Quarello Demarcos (2011): De Viaje por el mundo hispano, A2/B1, CIDEB

8. M. de Prada, P. Marcé, M. Bovet (2016): Entorno Turístico Nivel B1, Edelsa, Madrid

Svi navedeni udžbenici namenjeni su studentima radi usavršavanja veština verbalne komunikacije, pisane komunikacije (korespondencija, ugovori, turistički tekstovi) i veštine razumevanja. Priručnici i knjige su namenjeni studentima španskog jezika, kao i budućim stručnjacima u oblasti poslovanja, turizma i hotelijerstva. Reč je o udžbenicima za jezik struke za posebne namene, koji prikazuju niz realnih situacija, a kroz interaktivne vežbe student uči da komunicira na španskom jeziku. Preduslov za korišćenje nekih od ovih udžbenika je prethodno znanje opšteg jezika na srednjem nivou.

\section{ZAKLJUČAK}

Imajući u vidu specifične potrebe naših studenata i studentkinja kada je u pitanju usvajanje engleskog $\mathrm{i}$ španskog jezika kao stranih jezika sa najvećim brojem studenata na Poslovnom fakultetu i Fakultetu za turistički i hotelijerski menadžment Univerziteta Singidunum (engleski jezik kao obavezan predmet na sve četiri godine studija i španski jezik kao izborni predmet), možemo zaključiti da je dosadašnja praksa na ovom univerzitetu pokazala odlične rezultate. Naime, kurs engleskog jezika koncipiran je na nižim godinama osnovnih akademskih studija (prva i druga godina) kao opšti kurs jezika, a na višim godinama osnovnih akademskih studija (treća i četvrta godina) kao jezik struke, dok je kurs španskog jezika koncipiran na način da se pored opšteg jezika i ujednačenog razvijanja sve četiri jezičke veštine, od početnog nivoa učenja uvodi i terminologija i jezičke strukture koje su u vezi sa turizmom i hotelijerstvom, kao i da se istovremeno podstiče usavršavanja znanja iz različitih disciplina koje su neodvojive od konteksta struke (kultura, umetnost, istorija, geografija, itd). Preporučeni pristup autorki ovog rada bio bi učenje kroz komunikativne jezičke zadatke. Fokus na formu, svakako, nije zapostavljen. Svaki zadatak u sebi sadrži sve jezičke veštine, zastupljeni su kognitivni procesi i definisani komunikativni ishodi. Leksika, gramatika, kultura i komunikacija u realnom stručnom kontekstu turističkog i poslovnog sektora neodvojivi su elementi u okviru integrisanog učenja jezika i sadržaja. Od materijala za učenje, pored udžbenika koji nikada nisu idealni, niti jedini izvor znanja i informacija, ali jesu adekvatni 
za studente i silabuse na ovim akademskih programima, neophodno je koristiti realne uzorke jezika struke (u pisanom i usmenom obliku) iz drugih izvora - pre svega oslanjajući se na internet i nove tehnologije (audiovizuelni sadržaji, web stranice i portali, elektronski mediji). U oba slučaja, i kursevi engleskog i kursevi španskog jezika u velikoj meri jesu zasnovani na jeziku struke kao na dodatnom materijalu, uz preporuku autorki ovog rada da se takva praksa nastavi i pojača i u svim budućim nastavnim procesima na Univerzitetu Singidunum.

\section{LITERATURA}

[1] J. M. Bonet. "El español: una lengua viva", Informe 2017, Instituto Cervantes,internet: http://www.cervantes.es/sobre_instituto_cervantes/prensa/2017/ noticias/Presentaci\%C3\%B3n-Anuario-2017.htm , 27.11.2017. [1.april 2018]

[2] Turespaña, Portal Oficial para la promoción de España,

http://estadisticas.tourspain.es/es-es/estadisticas/fichadecoyuntura/paginas/default.aspx [4 .april 2018]

[3] P. Balboni, "La microlingua del turismo come 'fascio di microlingue", en Microlingue e letteratura nella scuola superiore, Brescia, La Scuola, 1989, pp. 56-61.

[4] P. Lerat. Las lenguas especializadas. Madrid. Ariel: 1997, p. 16

[5] M. López, El anglicismo en el español actual, Madrid, Arco Libros, 1998.

[6] R. Scollon, S.Wong Scollon, Intercultural Communication. Oxford UK \& Cambridge USA: Blackwell, 1995.

[7] E. Coseriu, Teoría del lenguaje y lingüística general, Madrid: Gredos, 1990. 